\title{
THE EFFECT OF CHAOS MODERN STRATEGIC MANAGEMENT TECHNIQUES ON FIRM PERFORMANCE
}

\author{
DOI: 10.17261/Pressacademia.2021.1406 \\ JBEF- V.10-ISS.2-2021(3)-p.72-87

\section{Yildiz Unsal', Erkut Altindag ${ }^{2}$} \\ ${ }^{1}$ Beykent University, Institute of Social Sciences, Department of Business, Istanbul, Turkey. \\ yildiz.ozturk@outlook.com, ORCID: 0000-0002-8635-8649 \\ ${ }^{2}$ Beykent University, School of Economics and Administrative Sciences, Istanbul, Turkey. \\ erkutaltindag@beykent.edu.tr, ORCID: 0000-0003-0173-0454
}

\begin{tabular}{l}
\hline Date Received: March 11, $2021 \quad$ Date Accepted: June 21, 2021 \\
\hline To cite this document \\
Unsal, Y., Altindag, E., (2021) The effect of chaos modern strategic management techniques on firm performance. Journal of Business, Economics \\
and Finance (JBEF), 10(2), 72-87. \\
Permanent link to this document: $\underline{\text { http://doi.org/10.17261/Pressacademia.2021.1406 }}$ \\
Copyright: Published by PressAcademia and limited licensed re-use rights only.
\end{tabular}

\section{ABSTRACT}

Purpose- The main aim of the study is to reveal the effects of chaos theory and blue ocean theory, which are modern strategic management techniques, on the general performance of firms. According to the literature, financial and growth performances are expected to increase, especially in firms developing an inimitable production system that produces innovative products and services. In this context, the research focused on identifying firms using these techniques and measuring their performance by employing the survey method.

Methodology- In the relational screening model, which is one of the quantitative data-based screening models, data collected from 204 people selected by the random sampling method from Istanbul province using the Chaos Theory Survey, Blue Ocean Scale, and Performance Analysis Scale were analyzed.

Findings- According to the data obtained from the results, there is a positive relationship between chaos theory and blue ocean strategy and firm performance. In other words, the growth and financial performances of firms that integrate new-generation management practices into their companies increase significantly.

Conclusion- According to the data obtained from this study, it is thought that managers who know and can apply chaos strategy may contribute to enhancing the firm's performance. It is believed that blue ocean strategy may help firms identify new ways that will make competition in the existing market meaningless. Furthermore, it is thought that testing chaos and blue ocean strategies in the context of Turkey can guide firms in the strategy determination stage.

Keywords: Chaos theory, Blue Ocean strategy, firm performance. JEL Codes: L10 L12 L13

\section{INTRODUCTION}

As a result of developing technology and increasing diversity in the service sector, the ability of firms to survive in the business world requires a successful management model. Nowadays, along with the increase in competition, firms need qualified managers and employees to survive. Managers should be able to apply an appropriate strategy and use modern management techniques successfully to increase firm performance. Firms should also be open to innovation to compete with other firms in the market. Managers who can apply modern strategic management techniques and a firm's culture that is open to innovation are needed for high firm performance. The main aim of this study was to investigate whether chaos theory and blue ocean approach, which are modern strategic management techniques, had effects on the performance of firms.

It is very important that firms can apply strategic approaches that are open to new ideas, innovative and able to create a new order under the changing conditions in order to increase their performance. For this purpose, managers should adopt innovations and should be able to use modern management methods instead of conventional methods. Under today's competitive conditions, it has also become more important for firms to have managers who are open to new ideas, know the blue ocean strategy and have a grasp of chaos theory. At this point, it is also of great importance for firms to be able to create an innovative firm culture to achieve success. 
In this study in which chaos theory and blue ocean strategy, which are modern strategic management techniques, were examined, the effects of these modern management techniques on firm performance were investigated. If they had effects, what kinds of effects, positive or negative, they had was investigated. The shift from the conventional management approach to the modern management approach that has been differentiated under today's changing competition conditions has created a platform where many different practices are experienced for organizations. Modern and postmodern approaches are a system of thought that criticizes scientific approach and knowledge, has a perspective to address everything relatively, and is mainly open to individuals' creativity, difference and interpretations. This approach, which finds freedom suitable instead of imposing the truth and envisages the evaluation of events in their course by refusing to find the truth and to make a prediction by scientific research, has also significantly affected practices in organizations

\section{CONCEPTUAL FRAMEWORK}

\subsection{Chaos Theory}

The chaos theory proposed by the US-born mathematician and meteorologist Edward Norton Lorenz (1917-2008) is a paradigm that offers a new perspective for the business world, far from being just a theory. This concept, chaos theory, which can be dated back to the ancient Greek and Chinese civilizations, primarily concerns mathematics and physics and then meteorology, economics, and business disciplines and has also changed the approaches of employees in management and organization discipline, is an important example of interdisciplinary study. Important studies on the theory were conducted by the French mathematician Henri Poincare before Lorenz. Other contributors to the theory were Kurt Lewin (unfreezing, changing and refreezing) and Rene Thom (disaster theory) (Koçel, 2005: 492: Gökmen, 2009: 67).

Chaos theory, which is considered as an irregularity, undesirable situation and based on the assumption that there is also something unknown, although everything is known, emphasizes that we should look at events from different perspectives and should collect data continuously for effective management. However, since there may be continuous and sudden changes in these collected data, they do not enable us to make a correct prediction but just bring us a little closer to correct prediction (Yakut, 2018), and we should keep in mind that chaos is not a disaster (Ertürk, 2012: 860; Armour, 2016; Arıcıoğlu and Karabıyık, 2019).

Along with the use of chaos theory in management, management approaches before and after the chaos should be examined to understand the circumstances that have caused it and how the process has taken place. In this way, the main features and dynamics of the change in the management approach can also be found out. It is known that a scientific method is primarily important in the conventional management approach. It is clear that science affects all kinds of perspectives. It was inevitable that scientific theories such as quantum and relativity, which emerged in the early 20th century, also affected the management field in the same way. Chaos theory, which is a new formation in science (Eden, 1994: 6; Burns, 2009), has now brought the perspective in which the connection, interaction, and harmony among social actors have come to the forefront, and thus, individuals should be provided with more freedom, initiative, and self-realization opportunities and should have a say in management, rather than authority and hierarchical relationships. The chaos approach is a more flexible, linear (Fatih, 2018) and non-hierarchical abstract thought against the dominant management approach (Yüksel, and Esmer, 2019). This new formation has led to the requirement that managers should adopt organization that can comply with environmental changes more easily with an integrated approach suitable for teamwork instead of detailed plans, inspection, and routine activities. Individuals at the management level should enter into a process that attaches importance to the individual and, therefore, organizational development and continuous learning, and thus, is not closed to change (Çavuş et al.), is open to adaptation to it (Öge, 2005: 301, and can take place in the long term by moving away from the conventional management approach and with a common vision, and they should virtually create "organized chaos" (Turunç, 2008: 62).

Traditional leadership theories may be insufficient for today's organizational expectations in the future. Future leaders should understand chaos theory and should be able to use it to interpret organizational events. The fact that managers who know chaos theory offer solutions to problems more easily has been revealed by the studies. Therefore, it is clear that one dimension of chaos theory should be leadership (Altun, 2001: 454-455: Galacgac and Singh, 2016: 521).

Chaos theory has four main propositions (Erol, 2009: 134):

- There is a sensitive commitment to the initial point.

- $\quad$ Every order tends to be destroyed. This law, namely entropy, can be roughly explained as follows: "everything goes downhill." According to Rudolf Clasius (1854), all natural processes are exposed to entropy (Eden, 1994: 6).

- New order results from the disorder. Although combined elements initially seem to be irregular and stacked, they establish regular relationships after a while. 
- There are asymmetrical relationships. Asymmetric order develops in an unpredictable direction through a selforganizing process (Thiétart and Forguez, 1995: 19).

Chaos theory now has a definition different from the mechanical universe of modernity that does not allow coincidence, and its linear geometry. Chaos theory, which has fractal, non-linear, and ontologic features, argues that the interaction between different systems cannot be measured in a controlled manner when they meet each other (Çıraklı, 20017) because it is not clear which variable interacts with what, and in this context, chaos theory invalidates the classical science's prediction of estimating the consequences of intervention to a variable (Demirtaş, 2000: 356).

Chaos theory is associated with nonequilibrium theory, self-organization theory, non-linear dynamics, complex systems, and complex adaptive systems (Gökmen, 2009: 66). Furthermore, it is also related to the concepts of determinism, butterfly effect, randomness, complexity, coincidence, and ambiguity (Kahyaoğlu, 2015; Öztürk and Kızılkaya, 2017).

\subsection{Blue Ocean Strategy}

The severe competition caused by globalization has seriously affected businesses, and innovations made by them in the existing market have become insufficient (Kişi, 2017). Therefore, firms need to create new markets that will make competition meaningless. Businesses have to create a new market and develop blue ocean strategies with an innovative approach, instead of competing in the existing red oceans (Kazdal, 2013: 76).

Blue ocean strategy is a term developed by W. Chan and Renee Mauborgne at INSEAD and Harvard universities. The blue ocean strategy recommends that firms should develop strategies to make competition meaningless instead of competing in their environment. It recommends that they should create new demand; in other words, they should create a market place and make a radical difference. The blue ocean strategy recommends that they should offer different and higher value to their customers at a low cost. Firms should make some eliminations and reductions within themselves by evaluating their own conditions to offer high value at a low cost, or in other words, to make value innovativeness (Leavy, 1996; Rau, 2012) (Kalkan et al., 2009: 1-12).

In a conversation with Kim and Mauborgne, authors of the "Blue Ocean Strategy," they were asked why blue and red colors were chosen for the oceans, and they stated that the competition struggles of firms made the environment bloody; therefore, it was called red, on the other hand, blue color symbolized the entire universe. The term blue ocean is a term used to describe a large, deep and unexplored area ( Kim and Mauborgne, 2005: 106).

When organizations created more detailed business processes and developed strategies to establish more effective control mechanisms on employees in order to increase efficiency that is effective in profitability, which is their purpose of establishment, and to provide a competitive advantage, qualified employees who got bored from it started to move away. This bloody and contentious competition area began to lose its functionality. In such a case, it was attempted to get out of the red ocean, and the blue ocean strategy was developed. The blue ocean strategy was developed by Mauborgne and Kim (Akdemir and Ömür, 2016). In their study, they examined a period longer than a century and thirty different industrial areas, they analyzed 150 strategic moves and demonstrated that the leading firms of the future could be successful in the uncontentious market place, namely the blue ocean (Baltaş, 2015; Yiğit, 2015).

The blue ocean strategy is also a modified strategy and draws attention to the importance of low cost. This strategy proposes a radical strategy to the product range and market limitations for consumers. Firms should increase the standard of service higher than average and provide higher opportunities than competing firms. The blue ocean strategy recommends that firms should develop a strategy that is capable of determining their environment instead of the determination of their strategies by the environment (Kalkan et al., 2009: 1-12; Baykal and Mızrak, 2019). Although the strategy has existed for a very long time, it has been named recently.

Blue sky and sea represent freedom, peace and eternity. Blue also represents reliability, honesty, and quality. On the other hand, while red is a symbol of power, excitement and power, it has also been symbolized as the color of hell and devilry as well as being a color that is frequently associated with danger such as blood and fire in nature (Mazlum, 2011: 131). When the blue ocean strategy is mentioned, the connotation of blue is positive.

The principles of the blue ocean strategy determined by Kim and Mauborgne (2010: 45-144) and the ways to achieve them offered by them are as follows:

- Reconstruct market boundaries

- Focus on the big picture, not numbers

- Reach beyond the existing demand 
- Get the strategic sequence right

The steps of the blue ocean strategy and the things to evaluate in each step are presented in Table 1 (Kim and Mauborgne, 2014: 118-119).

Table 1: Steps of the Blue Ocean Strategy

\begin{tabular}{|c|c|}
\hline STEP & QUESTION TO ANSWER \\
\hline 1. BUYER BENEFIT & Does the idea contain an extraordinary buyer benefit? \\
\hline 2. PRICE & Does the price of the product appeal to the audience? \\
\hline 3. $\quad$ COST & Is the determined strategic price in line with the cost target? \\
\hline 4. ACCEPTANCE & $\begin{array}{l}\text { What are the obstacles encountered in the acceptance phase of the idea? Are these } \\
\text { obstacles addressed from the beginning of the process? }\end{array}$ \\
\hline
\end{tabular}

It will be helpful to compare the blue ocean strategy with the red ocean strategy to understand its place among competition strategies (Table 2).

Table 2: Comparison of the Red Ocean Strategy and the Blue Ocean Strategy

\begin{tabular}{|l|l|}
\hline Red Ocean Strategy & Blue Ocean Strategy \\
\hline Competition in the current market area & Creating a conflict-free marketplace \\
\hline Competing in the competition & Don't make competition unreasonable \\
\hline Using the current claim for itself & Creating and obtaining new demands \\
\hline Exchange value-cost & Breaking the value-cost exchange \\
\hline $\begin{array}{l}\text { To harmonize the entire system of company activities with } \\
\text { the strategic choice between differentiation and low cost }\end{array}$ & $\begin{array}{l}\text { To harmonize the entire system of the company's activities } \\
\text { while trying to realize differentiation and low costs }\end{array}$ \\
\hline
\end{tabular}

Source: Güneş, Serkan. "Değer Yaratma Bağlamında Güncel Dört Yenilik Modeli [Four Contemporary Innovation Models in the Context of Creating Value]", Sanat ve Tasarım Dergisi, 2011, Sayı Nu.7, kutuphane.dogus.edu.tr/mvt/ pdf.php? recid=12172\&pdf=0012162 (23 Mayıs 2015). Inspired by Kim and Mauborgne (2005).

A number of strategic actions are performed to realize the principles of the blue ocean strategy. These tools are the value renewal and the four-action framework.

Interestingly, blue ocean strategists who did not set competition as a criterion for themselves adopted a different strategy logic called value renewal. The reason why this strategy was called value renewal was that businesses created a new and uncontentious market place by focusing on making competition meaningless by creating value for purchasers and themselves, instead of focusing on outperforming the competition (Kim and Mauborgne, 2014: 12).

Four questions posed by the four-action framework, which is a tool to create a new value, to reduce the contradiction between differentiation and low cost, and their goals are as follows (Table 3) (Ergen, 2015: 10):

Table 3: Four-Action Framework

\begin{tabular}{|l|l|}
\hline Handle / Destroy & What factors should the industry meet naturally? \\
\hline Decrease & What factors should be reduced below the industry standard? \\
\hline Increase & $\begin{array}{l}\text { What factors should be increased that the industry has not previously } \\
\text { proposed? }\end{array}$ \\
\hline Create & What factors should be created above the industry standard? \\
\hline
\end{tabular}

Source: Ahu Ergen, "Stratejik Düşünce Yaratma: Mavi Okyanusa Yelken Açmak [Creating Strategic Thinking: Sailing the Blue Ocean]", Bahçeşehir Üniversitesi Dergisi, http://pazarlama.org.tr/dergi/yonetim/icerik/ makaleler/21-published.pdf (21 Temmuz 2015: 10).

The firm called "Cirque du Soleil" operating in the circus industry (Kim and Mauborgne; 2014: 3-4, Baltaş; 2015), Yellow Tail producing wine in Italy (Hein, 2005), and iPhone can be shown as the examples of the application of the blue ocean strategy.

Along with the concept of blue ocean, the term "blue ocean leadership" emerged for leaders who can apply this strategy to the literature. According to Dorf, blue ocean leaders should create their leadership canvases by analyzing their environment well. Leadership in the role model profile becomes important at this point. Furthermore, it is also important that they make efforts to institutionalize new leadership practices. Dorf, who stated that poor leadership practices were surprising in many firms studied, 
indicated that blue ocean leadership canvases could provide more concrete examples of business life for ideal leadership (Dorf, 2014: 60-72).

According to Kim and Mauborgne (2010: 150), there are four organizational barriers to strategy formulation, which are the Cognitive barrier (status quoism), Resource barrier (limited resources), Political barrier (against strong stakeholders), and Motivational barrier. While employees' inability to see that radical change is necessary constitutes the cognitive barrier, businesses' problems and difficulties in reaching certain resources constitute the resource barrier, the factors that discourage and demoralize employees constitute the motivational barrier, and strong resistance to change by looking out for various interests constitutes the political barrier (Kim and Mauborgne, 2014: 150).

It is paradoxical to define the shift from the red ocean strategy to the blue ocean strategy. If the blue ocean strategy is positioned as a strategy that should be preferred, it becomes difficult to explain a large number of organizations in the red ocean. In their study on 108 newly established organizations, Kim et al. (2004) found that 84 percent of them felt much more comfortable in red oceans, and only 14 percent of them made efforts to create new markets and industries. Moreover, although the share of red ocean followers in total profit was higher in number by $39 \%$, the ratio of those who adopted the blue ocean was $38 \%$. They explained the reason why the red ocean strategy was still preferred as follows: The rules of war are valid in any environment with competitors, and the strategy is determined as the sharing of a particular region by those who fight for that region. In the blue ocean strategy, there is no competitor. It is necessary to find new lands instead of sharing the existing land. In this case, it is clear that those who remain in the red ocean must defeat their enemies to be successful. Of course, competition is important. However, the point to remember is to explore blue oceans where there is no or scarcely any competition and to keep them blue, and this is a strategy that should be focused on.

\subsection{Firm Performance}

Performance is quite a controversial issue with regard to what it is on it. It may be quantitative or qualitative. Even if the same operation occurs, the performance of the job or the person who does that job may be low or high with different perspectives, or performance criteria can be shaped according to expectations. Regardless of the criteria used in firm performance or no matter which method is used in which measurement, the qualities of a good performance measurement are as follows: It should give information, provide improvement, be understandable, current and timely, be meaningful, be flexible, be appropriate (Zerenler, 2003: 204-205).

The studies measured the firm performance in four dimensions: yield, product quality, profitability, and market share (Özutku and Çetinkaya, 2012: 356; Karamustafa et al., 2009: 100-119). These criteria, which are the most commonly used criteria in the measurement of organizational performance, are also the goals of an organization's existence. Mutluay and Turaboğlu (2013: 66) took as a basis the rates obtained from financial statements and profitability as a criterion while measuring the firm performance, and they used ROCE (Return on Net Capital Employed) as a performance criterion.

In general, it appears that seven criteria are used as criteria in firm performance in the literature. These criteria are efficiency, utilization of yield and inputs, productivity, quality, innovation, quality of working life, profitability and budget compliance (Akal, 2000: 15). In addition to these performance criteria, Zerenler and İraz (2006: 262) also mentioned the criteria of customer satisfaction, cost reduction, capacity increase, increased productivity of employees, sales increase, production of salable products, and increased social responsibility.

In their study, Meyer and Gupta (1994: 309-369) stated that performance and performance appraisal were paradoxical and that different firms used different performance appraisal methods formed in the literature, and they explained these methods as follows (Elitaş et al., 347-368):

- Lynch-Cross Performance Pyramid: It is a two-dimensional approach that focuses on "what" an organization will achieve and "how" an organization will achieve it. The left side of the pyramid consists of external customeroriented scales, and the right side of it consists of organization-oriented internal criteria. The mission and vision of the organization are at the top of the pyramid. Organizational performance indicators are market (commercial and financial measures) and financial (profit, cash flow, balance sheet and income tables, the place of products put on the market in the last year in total sales, etc.).

- Balanced Scorecard Technique Approach: This measurement, which was included in the literature with the article "The Balanced Scorecard-Measures That Drive Performance" published by Kaplan and Norton in the Harward Business Review, measures firm performance in four dimensions: financial dimension, customer dimension, internal function dimension, and learning and growth dimension (Elitaş et al., 347-368; Kaplan and Norton, 1996: 53-79). 
- The Stakeholder Scorecard Approach: In this model developed by Atkinson et al. (1997), firm performance is based on stakeholders. This method, which focuses on integrating the needs and expectations of the organization's stakeholders (customers, employees, suppliers, partners, and society) properly and on measuring how they do them, focuses not only on financial and non-financial performance indicators but also on the relationship between the organization and stakeholders (Ağca, 2006: 178).

- Performance Prism Approach: In this performance measurement method, which was proposed by Kennerly and Neely mostly as the "second generation" performance measurement management, there is a different factor on each of the five surfaces of a prism: stakeholder satisfaction, strategies, processes, capabilities, and stakeholder contribution. Its biggest advantage over other methods is that it takes into account all stakeholders of the organization (investors, customers, employees, suppliers, legislators) and their demands and needs.

In addition to these firm performance measurement methods, there are also Rate of Return on Investment (ROI), Sink and Tuttle Model, Brand Valuation, Customer Value Analysis, Activity-based costing (ABC), Economic Value Added (EVA), and the Perfection Model (Yüreğir and Nakıboğlu, 2007: 549-557).

\section{STUDIES ON CHAOS THEORY, BLUE OCEAN STRATEGY, AND FIRM PERFORMANCE}

A small number of studies examining the relationship between chaos theory, blue ocean strategy, and firm performance was a limitation of this study. However, the studies on these concepts were included to contribute to the studies on chaos theory and blue ocean strategy.

In his case study on Blue Ocean on 14 firms stating that they used the blue ocean strategy in Malaysia, Mohammed (2009: 30-34) examined the blue ocean strategy in four categories (Kim and Maugborgne's four actions: eliminate, reduce, raise, and create) and revealed that these firms fulfilled the requirements of the strategy. These four actions are called eliminate, reduce, raise, and create.

In their study on value-based innovation models in the blue ocean strategy in Italy, Borgianni et al. (2012: 123-142) analyzed Motorola Iridium as an example of failure and Nintendo Wii organization as an example of success, and they attempted to reveal the share of New Value Propositions in this success and failure and emphasized the importance of its place in the blue ocean strategy. According to them, new propositions were a type of value-based innovation.

In their study on 41 different types of retail stores in Holland between 1982 and 2000 (the retail sector was chosen because it is very competitive and innovative), Burke et al. (2009) compared the blue ocean strategy with Porter's five power models and found that the blue ocean strategy was more sustainable. Nevertheless, they emphasized that the strategy needed to be adopted by organizations was a mixture of both. While a competitive strategy is followed to reduce profit erosion for the existing markets, it is possible to set sail for the blue ocean strategy for untouched markets.

In his study, Chang (2010: 219-223) examined the blue ocean strategy applied for bandit mobile phones, an anonymous brand sold by MediaTek in the People's Republic of China, and he found that the organization created a different strategy canvas with this strategy and that especially the tablet industry tended to imitate it. MediaTek's strategy can be an example of innovation management. Chang also stated that a good blue ocean strategy should be inimitable and that it could be done only by creating value.

In their study on the applicability of the blue ocean strategy in the B2B (Business to Business) industry, Cirjevskis et al. (2011: 201215) worked with SIKA AG firm serving in the chemical industry and ALEXANDRA PLUS LLC firm serving in the industrial treatment industry and showed that the blue ocean strategy was also functional in organizations operating in the B2B sector.

In their study, Giannoulis et al. (2012: 118-128) aimed to associate the business strategy formulation of Schumpeter's idea with the information system development, and they provided guidance on how to adopt this strategy by creating various blue ocean strategy maps.

Kovaleski (2010) explains the results of Nintendo's conference about the blue ocean strategy as follows: When Nintendo started to become weak in its competition in the video game industry, it developed a new tactic instead of continuing this competition. They targeted different groups, such as women, adults and families, rather than producing more options for the traditional target group (male youth). There is now Wii that will attract even those who do not play video games on the platform. This is an example of the blue ocean strategy.

Lindic et al. (2012: 928-938) examined the effect of the blue ocean strategy, which is an example of entrepreneurship, on very large-scale growth. Their starting point was that the size of the firm was important in determining strategies and the effect of 
each strategy on firms of all sizes was different. They concluded that the blue ocean strategy could also be effective in organizations that desired rapid growth.

Wengel et al. (2010: 56) examined the blue ocean strategy on the model created by Schumpeter based on data of the Colombian National Department of Statistics on the economies of size of some of 8000 firms in Colombia over a 12-year period. These organizations that were examined through innovation and economy of scale, which were considered to have effects on productivity by Schumpeter, showed that the blue ocean strategy was effective on total efficiency and productivity.

In their study, Tu et al. (2014: 1-23) aimed to determine how the blue ocean strategy was used in sustainable product design and what kind of effect the Bottom/Base of the Pyramid (BOP) had on creating job opportunities that may affect the customer profile in Taiwan, and their conclusions are as follows: 1 . Since the consumption characteristics and behaviors of customers belonging to the subgroup are different, it should be taken into consideration in product design. 2. Since there is a broad market for this customer profile in Taiwan and regional and low income differences affect consumption, a general market assessment should be performed to identify real business opportunities. 3. High quality and low price are the most important criteria to influence the customer. 4. It should be considered that distribution channels also affect the use of customers and the recycling of products.

Becker (2013: 472-476) attempted to explain the transition of the Canadian film production and distribution company called IMAX from normal-length and screened films to producing Holywood movies in the IMAX format through the story analogy "Who Moved My Cheese?". In this story telling the struggle of two people named Mırın and Kırın and two little mice named Koklarca and Koşarca to find cheese in a labyrinth, the labyrinth is the metaphor of the place where our struggle for life takes place, and cheese is the metaphor of our wishes and desires. In this story, the problems that an individual would experience when he/she did not adapt to change and did not easily forget the old days and turn towards innovation, and the fact that recognizing small changes might increase adaptability were explained through a metaphor. Becker also compared IMAX's change in the film industry to these story heroes struggling to find a new one to replace the depleted resource.

Barwise et al. (2012: 24-27) attributed the rise of Samsung in the mobile phone market and its superiority over iPhone and Nokia to the blue ocean strategy. They explain this growth with four main reasons:

- Making clear and precise promises to the customer

- Gaining customer's confidence by fulfilling this promise

- Leading the sector by always growing and moving their promises forward

- Being in search of creating a different advantage with an understanding of innovation other than the popular opinion

According to Barwise et al. (2012: 27), it is not possible for the color of the ocean to remain blue. At any moment, each mobile phone company may fall behind the competition again in this blurred ocean by falling into the situation of Motorola or Nokia.

Kim et al. (2008: 522-533) conducted a study to analyze the blue ocean strategy in the business model of Cheil Jedang' s-Global Logistics Service (CJ-GLS) organization, which is headquartered in Seoul, South Korea, and provides worldwide logistics service, and they provided very significant information on how this organization achieved a competitive advantage by using information technologies in their transition from the red ocean strategy to the blue ocean strategy. In this case analysis study, the competitive advantage achieved by the blue ocean strategy was discussed by interviewing the organization's CEO and $\mathrm{CIO}$ and focusing on the core competence of the organization. They showed building a highly motivated information strategy team, senior management leadership, and an open mindset as the key points for success.

Gündüz (2019) indicated that the use of the blue ocean strategy not only in the management of firms but also in the management of higher education would contribute to education by opening new horizons. Furthermore, Gündüz $(2016,2018)$ also stated that a firm using a blue ocean strategy would be imitated immediately and explained how to get back into the blue ocean in such a case through an example of a "game of escaping from a house."

Many studies were conducted on chaos theory. The study carried out by Bright et al. (2005: 291 305) on the place of chaos theory in career prediction is interesting. Career development depends on many factors, takes place at different speeds and levels under different conditions and has a very complex structure. It is necessary to start from the assumptions of chaos theory in career planning.

Pryor et al. (2009: 39-50) used the "game" metaphor for a career. In their study, they aimed to contribute to career counseling by associating the game metaphor with chaos theory. Game analogies may help in understanding chaos theory. In their study in which they attempted to explain how the implementation of chaos theory would be helpful especially for the customer profile, 
interested in sports and coming to get career counseling, they emphasized that the continuous change in the contemporary business life and the complexity and uncertainty caused by the interconnection of systems should be overcome, which could be possible only by career development.

In their study, Speakman et al. (2012: 67-77) made a proposition based on chaos theory as an alternative model to crisis management by indicating that the crises and disasters in the tourism sector could not be explained by linear systems and that contemporary crisis management models were therefore limited. The swine flu (AH1N1) experienced in Mexico in 2009 was one of the biggest crises in the tourism sector, and they stated in their studies how modern crisis management methods were ineffective during this period. A campaign called "Vive Mexico" was launched to overcome this crisis, and the sector was revived again. While the authors emphasized that this practice was not surely very new as a marketing strategy, they stated that their study was aimed at emphasizing the importance of adopting the principles of chaos theory since the tourism sector was especially very chaotic.

Akmansoy et al. (2014: 510-518) indicated that the paradigm of chaos theory was also applied in social sciences as well as in natural sciences, and they examined the effect of this theory in the field of education. In their case study conducted with 30 faculty members of Burdur Mehmet Akif University Faculty of Education, Faculty of Arts and Sciences, and Faculty of Veterinary Medicine, they studied the "butterfly effect" in education and drew attention to what a small mistake might cause. The questions to which they sought answers were "How does a mistake affect the student's future education?", "How does a negativity in the university affect the student's attitude towards the university?", "How is education affected by students at different levels?", etc.. They stated that considering chaos theory in the field of education would give university administrators a different spirit.

In their case study, Özen et al. (2013: 130-135) discussed in what ways solutions could be found in certain events with the rules of chaos theory from the perspective of an education director and a student. Addressing educational issues from the perspective of chaos theory may also help managers in the field of education to overcome the problems they face in education that witnesses rapid changes, by giving them a different perspective.

\section{DATA AND METHODOLOGY}

In this study, firm performance was considered as a dependent variable and chaos theory and blue ocean strategy were considered as independent variables, and their effect on firm performance was examined. No mediating variable was used. Sociodemographic variables were included in the scale questionnaires by considering that they could only shed light on later studies. The effect of sociodemographic variables was not included within the scope of this study.

H1. There is a positive relationship between the factors of chaos theory and firm performance.

$\mathrm{H} 2$. There is a negative relationship between the factors of the red ocean strategy and firm performance.

H3. There is a positive relationship between the factors of the blue ocean strategy and firm performance factors.

People working in any sector constituted the main population of the study. Random sampling was performed, without considering in which sector they worked. The sampling method based on accessibility was preferred, and students in the institute where the researcher was doing a master's degree and the staff of the hospital where she worked were selected as a sample.

In determining the relationship between chaos theory, blue ocean strategy and firm performance; chaos theory and blue ocean strategy were used as independent variables and firm performance as dependent variables. Data entries were entered with a 7 point Likert scale, and all measurement tools were made ready for descriptive statistics and T-test.

In this study, firstly general information about the business and then information about the person are given. About the enterprise, the name of the enterprise, the boundaries of its field of activity, the sector in which it operates, the number of employees and the year of establishment were asked. About the employees, name and surname, department, title, age, gender, education level, total working time, working time in this workplace were asked. There are thirteen questions in total. Three hundred questionnaires were distributed, and 204 of them were collected. Since all data were sufficient, there was no unused questionnaire.

\section{EMPIRICAL RESULTS}

Two hundred four participants from Istanbul province selected by the random sampling method were included in the study. In the study, firstly, general information about the business and then sociodemographic information about the people were also included. While $2.5 \%$ of the firms where participants were working were in the food/beverage/tobacco sector, $1.5 \%$ of them were in the clothing/textile/leather sector, $0.5 \%$ of them were in the automotive industry, $32.4 \%$ of them were in the health sector, 
$0.5 \%$ of them were in the chemical/oil/tire industry, $45.6 \%$ of them were in other sectors, and $17.2 \%$ of them were in the information sector. The majority of the participants in the study consisted of people between the ages of 26-30, in other words, young people by $34.3 \%$. They were followed by participants between the ages of $31-35$ by $20.6 \%$. It can be said that the participants were mostly young and middle-aged. There was a close gender distribution among 204 participants consisting of 82 female (40.2\%) and 114 male (55.9\%) individuals. With regard to educational status, while $6.4 \%$ of the people who participated in the study were high school graduates, $2.5 \%$ of them were college graduates, $34.3 \%$ of them were university graduates, $54.4 \%$ of them had a master's degree, and $2.5 \%$ of them had a doctoral degree. According to this result, it can be stated that it was regarded that the employed people within the scope of the study would have a very high educational level.

\section{Reliability and Validity of Measurement Tools and Analysis of the Resulting Factors}

The 26-item Chaos Theory Survey, the 10-question Blue Ocean Strategy Survey and the 11-question Performance Evaluation Survey used in this study were tested for construct validity by factor analysis and reliability techniques.

Within the scope of the study, the survey results obtained from a total of 204 participants were examined by reliability analysis using the SPSS program, and the overall reliability level for 47 questions was found to be 0.906 , which was well above the limit value of 0.700 . The fact that the participants who have filled out the questionnaires perceive the questions correctly and give similar answers are the main factors that reliability analysis tries to measure. The scale reliability, which is determined to be 0.900 and above in the experimental studies, provides an excellent background to continue the study and to perform other analyses. However, the reliability analysis of each sub-factor was checked one by one except for the overall scale in order to leave no room for the scientific gap. Adequate values were obtained by performing the reliability analysis of all scales (Table 4).

Table 4: Reliability Analysis of All Scales

\begin{tabular}{|l|c|}
\hline \multicolumn{2}{|c|}{ Reliability Analysis } \\
\hline Factor & Cronbach's Alpha \\
\hline Chaos (26) & 0.881 \\
\hline Ocean (9) & 0.800 \\
\hline Performance (11) & 0.873 \\
\hline
\end{tabular}

While examining the blue ocean scale, the question number one was removed from the analysis because reliability analysis was decreased to 0.630 when this question was included in the scale. The first question was excluded from the analysis because there was a possibility that it could not be understood by readers, or there was an error of design. Thus, the next analysis can bring objective comments.

Two independent and one dependent variable were included in the model created in this empirical study. The chaos approach, which was the first independent variable, consisted of 26 questions, and the blue and red ocean variable consisted of nine questions. The firm performance, which was included as a dependent variable in the study, consisted of 11 questions. While it was planned to divide the chaos approach scale into four factors consisting of planning, communication, teamwork, and leadership, the ocean scale was planned to be divided into two factors consisting of the blue and red ocean. While the variables were included in factor analysis, the KMO levels were also evaluated.

The chi-square values of KMO ratios, including all three variables, are presented in Table 5.

Table 5: KMO and Chi Square Values

\begin{tabular}{|c|c|c|}
\hline Variable & KMO & Ki Kare \\
\hline Chaos & 0.931 & 3466.504 \\
\hline Ocean & 0.727 & 781.316 \\
\hline Performance & 0.922 & 1760.998 \\
\hline
\end{tabular}

In the reliability test performed for the collected data, Cronbach's alpha coefficients were found to be $0.881,0.800$, and 0.873 , respectively, for the Chaos Theory Survey, Blue Ocean Survey, and Performance Evaluation Survey. Since the result of Bartlett's test of sphericity performed for the data group was found to be $p<0.001$, it was found out that there was a significant relationship between the items of the scale. Since the KMO values were observed to be well above the limit value, the exploratory factor analysis, in which factor loads of each variable are determined, was performed for all three scales (Table 6, Table 7, Table 8). 
Table 6: Chaos Theory Factors and Factor Loads (Varimax Rotated Factor Matrix)

\begin{tabular}{ll}
\hline CHAOS THEORY & $\mathbf{1}$ \\
\hline Factor 1 PLANNING & 0,628 \\
9. We plan for other situations. & 0,562 \\
10. We consider problem solving strategies. & 0,558 \\
13. We apply systematic approach to problem solving. & 0,525 \\
14. We make a global assessment of the situation. & 0,710 \\
15. We re-evaluate to prevent errors. & 0,739 \\
17. We know the importance of expressing the problem. & 0,709 \\
19. In the event of a crisis, we do team work. & 0,611 \\
20. We give importance to delegation of authority. & 0,665 \\
23. We have the ability to organize a team. & 0,712 \\
24. We have priority tasks. & 0,791 \\
25. Otherwise, we call our friends for help. & 0,702 \\
26. We make predictions or plans for the future. &
\end{tabular}

\section{Factor 2 COMMUNICATION / TEAM WORK}

4. We have a good communication opportunity. $\quad 0,548$

6. We act voluntarily while asking for help. $\quad 0,815$

7. Our communication with our colleagues is very good. $\quad 0,687$

8. We work with a team. $\quad 0,613$

11. We communicate with our trainers in crisis $\quad 0,536$

management.

12. We have communication skills. $\quad 0,613$

\section{Factor 3 INITIATIVE}

1. Employees have the opportunity to apply the theory of chaos.

2. Employees have a good teamwork skill and duty authority.

3. There are moments when we have more control and less concern.

\section{Factor 4 LEADERSHIP}

16. We do not make predictions.

21. There are leadership problems in our company.

$-0,736$

22. Employees need a leader.

$-0,839$

Note: Table 6 shows the factor loads of the sub-expansions of chaos theory.

The results show that the chaos values are divided into factors within themselves, just as expected. The chaos approach is divided into 4 sub-factors. While determining the variables assigned to the factor, the variables whose factor load was below 0.500 were excluded from the analysis.

\section{Table 7: Ocean Scale Factor Analysis}

\begin{tabular}{lc}
\hline OCEAN & $\mathbf{1}$ \\
\hline Factor $\mathbf{1}$ RED OCEAN & \\
3.We do our best to win the competition. & 0,654 \\
5. We struggle to win the existing demand. & 0,670 \\
7. We make the cost seem insignificant. & 0,736 \\
$\begin{array}{l}\text { 10. We gather all the companies' activities and systems in a } \\
\text { common area and offer them at low cost. }\end{array}$ & \\
Factor $\mathbf{2}$ BLUE OCEAN & \\
2. We create a competitive marketplace. & 0,319 \\
4. We live in the area where there is no competition. & 0,505
\end{tabular}


6. We struggle as a company to create and capture nondemand.

8. We do not care about the cost value.

9. We collect each selected activity and system of the companies at a common point.
0,703

The results show that the ocean values are divided into factors within themselves. The ocean scale is divided into 2 sub-factors within itself. While determining the variables assigned to the factor, the variables whose factor load was below 0.500 were excluded from the analysis. Especially since the consecutive questions at the ocean scale contain opposite meanings, a high level of contrast was observed in the factor analysis.

Table 8: Firm Performance Factors and Factor Loads (Varimax Rotated Factor Matrix)

\begin{tabular}{ll}
\hline FIRM PERFORMANCE & $\mathbf{1}$ \\
\hline Factor $\mathbf{1}$ & 0,850 \\
Your average net profitability before tax & 0,870 \\
Net income from your core activities & 0,817 \\
Financial success of new products you put on the market & 0,852 \\
Your overall financial success & 0,869 \\
Average annual increase in your sales & Discarded \\
Increase in the number of new products you put on the market. & 0,798 \\
Increase in your market share compared to your leading & \\
competitors & 0,674 \\
Increase in the number of your employees & 0,654 \\
Increase in the number of new customers & 0,863 \\
In general, your position in the competitive environment in the & \\
market. & 0,856 \\
Your profitability level in general. & \\
\hline
\end{tabular}

The emerging results indicated that the ocean and chaos values were divided into factors within themselves, as it was expected. The chaos approach was divided into four sub-factors, and the ocean was divided into two sub-factors. While determining the variables assigned to each sub-factor within the scope of factor analysis, the variables with a factor load below 0.500 were excluded from the analysis. A high level of contrast was observed in factor analysis, especially since sequential questions in the ocean scale included opposite meanings. Before starting the correlation analysis, each factor was averaged and named. Thus, two independent variables were transformed into six different independent variables along with their sub-factors, which was positively reflected for the enrichment of the research model.

When the results of the correlation analysis performed on the scales within the scope of these statements (Table 9) were examined, it was observed that the first three factors of the chaos approach and the blue ocean sub-factor were mutually correlated with the firm performance. For example, it was observed that the performances of firms that focused on blue ocean techniques, operated in areas where there was no competition, and attached importance to innovation were correlated at the level of 0.582 . This significant positive correlation indicated that investments in the blue ocean might quickly and positively affect business performance. Another remarkable detail was that an intense correlation was found between the first three factors of the chaos approach and the blue ocean factor. When these two techniques are used together, it can be assumed that they will have a more significant effect on performance. However, it will be necessary to examine the results of regression analysis to make a definite judgment about it.

Table 9: Correlation Analysis Between Cases

\begin{tabular}{|c|c|c|c|c|c|c|c|c|}
\hline Dimensions & & & & & & Red & Blue & Firm \\
\hline & & Chaos & Chaos & Chaos & Chaos & Ocean & Ocean & Performance \\
\hline & & F1 & F2 & F3 & F4 & F1 & F2 & $\mathrm{F} 1$ \\
\hline Chaos Factor 1 & $\mathrm{p}$ & 1 & $0,765^{* *}$ & $0,647^{* *}$ & $-0,301 * *$ & $0,538^{* *}$ & $-0,013$ & $0,546 * *$ \\
\hline \multirow[t]{2}{*}{ PLANNING } & $\mathrm{s}$ & & 0 & 0 & 0 & 0 & 0,851 & 0 \\
\hline & $\mathrm{N}$ & 204 & 204 & 204 & 204 & 204 & 204 & 204 \\
\hline
\end{tabular}




\begin{tabular}{|c|c|c|c|c|c|c|c|c|}
\hline Chaos Factor 2 & $p$ & $0,765^{* *}$ & 1 & $0,622^{* *}$ & $-0,271 * *$ & $0,454 * *$ & $-0,023$ & $0,459 * *$ \\
\hline \multirow{2}{*}{$\begin{array}{l}\text { CONTACT/ TEAM } \\
\text { STUDY }\end{array}$} & $\mathrm{s}$ & 0 & & 0 & 0 & 0 & 0,739 & 0 \\
\hline & $\mathrm{N}$ & 204 & 204 & 204 & 204 & 204 & 204 & 204 \\
\hline \multirow{3}{*}{$\begin{array}{l}\text { Chaos Factor } 3 \\
\text { INITIATIVE }\end{array}$} & $p$ & $0,647 * *$ & $0,622 * *$ & 1 & $-0,180 * *$ & $0,388 * *$ & 0,037 & $0,436 * *$ \\
\hline & $\mathrm{s}$ & 0 & 0 & & 0,01 & 0 & 0,603 & 0 \\
\hline & $\mathrm{N}$ & 204 & 204 & 204 & 204 & 204 & 204 & 204 \\
\hline \multirow{3}{*}{$\begin{array}{c}\text { Chaos Factor } 4 \\
\text { LEADERSHIP }\end{array}$} & $p$ & $0,301 * *$ & $-0,271 * *$ & $-0,180 * *$ & 1 & $-0,137$ & $0,259 * *$ & $-0,306 * *$ \\
\hline & $\mathrm{s}$ & 0 & 0 & 0,01 & & 0,051 & 0 & 0 \\
\hline & $\mathrm{N}$ & 204 & 204 & 204 & 204 & 204 & 204 & 204 \\
\hline \multirow{3}{*}{$\begin{array}{l}\text { Ocean Factor } 1 \\
\text { RED OCEAN }\end{array}$} & $p$ & $0,538 * *$ & $0,454 * *$ & $0,388 * *$ & $-0,137$ & 1 & $0,265^{* *}$ & $0,582 * *$ \\
\hline & s & 0 & 0 & 0 & 0,051 & & 0 & 0 \\
\hline & $\mathrm{N}$ & 204 & 204 & 204 & 204 & 204 & 204 & 204 \\
\hline Ocean Factor 2 & $p$ & $-0,013$ & $-0,023$ & 0,037 & $0,259 * *$ & $0,265^{* *}$ & 1 & 0,036 \\
\hline BLUE & $s$ & 0,851 & 0,739 & 0,603 & 0 & 0 & & 0,611 \\
\hline OCEAN & $\mathrm{N}$ & 204 & 204 & 204 & 204 & 204 & 204 & 204 \\
\hline Firm Performance & $p$ & $0,546 * *$ & $0,459 * *$ & $0,436 * *$ & $-0,306 * *$ & $0,582^{* *}$ & 0,036 & 1 \\
\hline \multirow[t]{2}{*}{ Factor 1} & $s$ & 0 & 0 & 0 & 0 & 0 & 0,611 & \\
\hline & $\mathrm{N}$ & 204 & 204 & 204 & 204 & 204 & 204 & 204 \\
\hline
\end{tabular}

Note: * Correlation (relationship) at the 0.05 level \& ** correlation (relationship) at the 0.01 level is significant

The regression analysis performed for all scales is presented in Table 10.

Table 10: Regression Analysis for All Scales

\begin{tabular}{|c|c|c|c|c|c|c|}
\hline \multicolumn{7}{|c|}{ Coefficient } \\
\hline \multirow{2}{*}{\multicolumn{2}{|c|}{ Model }} & \multicolumn{2}{|c|}{$\begin{array}{l}\text { Non-standard } \\
\text { Coefficient }\end{array}$} & \multirow{2}{*}{$\begin{array}{c}\begin{array}{c}\text { Standard } \\
\text { Coefficient }\end{array} \\
\text { Beta }\end{array}$} & \multirow[b]{2}{*}{$\mathrm{t}$} & \multirow[b]{2}{*}{ Sig. } \\
\hline & & B & Std. Hata & & & \\
\hline \multirow{7}{*}{ 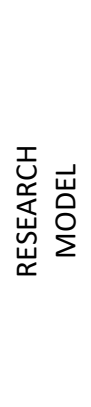 } & (Constant) & 1,947 & 0,45 & & 4,329 & 0 \\
\hline & PLANNING & 0,199 & 0,096 & 0,192 & 2,067 & 0,04 \\
\hline & COMMUNICATION / TEAM WORK & 0,004 & 0,088 & 0,004 & 0,047 & 0,962 \\
\hline & INITIATIVE & 0,124 & 0,074 & 0,119 & 1,66 & 0,098 \\
\hline & LEADERSHIP & $-0,136$ & 0,05 & $-0,159$ & $-2,755$ & 0,006 \\
\hline & BLUE OCEAN & 0,431 & 0,069 & 0,418 & 6,274 & 0 \\
\hline & RED OCEAN & $-0,028$ & 0,047 & $-0,035$ & $-0,61$ & 0,543 \\
\hline \multicolumn{2}{|r|}{ Model Summary: } & $R^{2}: 0,450$ & \multicolumn{2}{|c|}{ Adjusted $R^{2}: 0,433$} & \multicolumn{2}{|c|}{ Estimated S.H.: 0,79 } \\
\hline
\end{tabular}

When the beta coefficients of the variables in the model were examined, it was observed that three sub-factors had an effect on the dependent variable. While planning, one of the sub-dimensions of the chaos strategy, and blue ocean positively affected the performance, leadership had a negative effect on performance. It is observed that these three factors can explain $45 \%$ of changes in the dependent variable. This ratio is high at a level that is very rarely observed in numerical studies in social sciences, indicating how strongly the research model was designed. Another factor that may be surprising in the analysis results was that the red ocean factor was not found to be significant, although it tended to be negative. The assumption that firms that competed in the existing markets and did not attach importance to research and development activities would perform poorly, which was expected before the study, was found to be insignificant. This result does not show that the red ocean approach has a negative effect on business performance. In other words, while the blue ocean directly and positively affects the business performance, the presence of the business in the red ocean has no effect on the performance. 
Figure 1: Model of Research

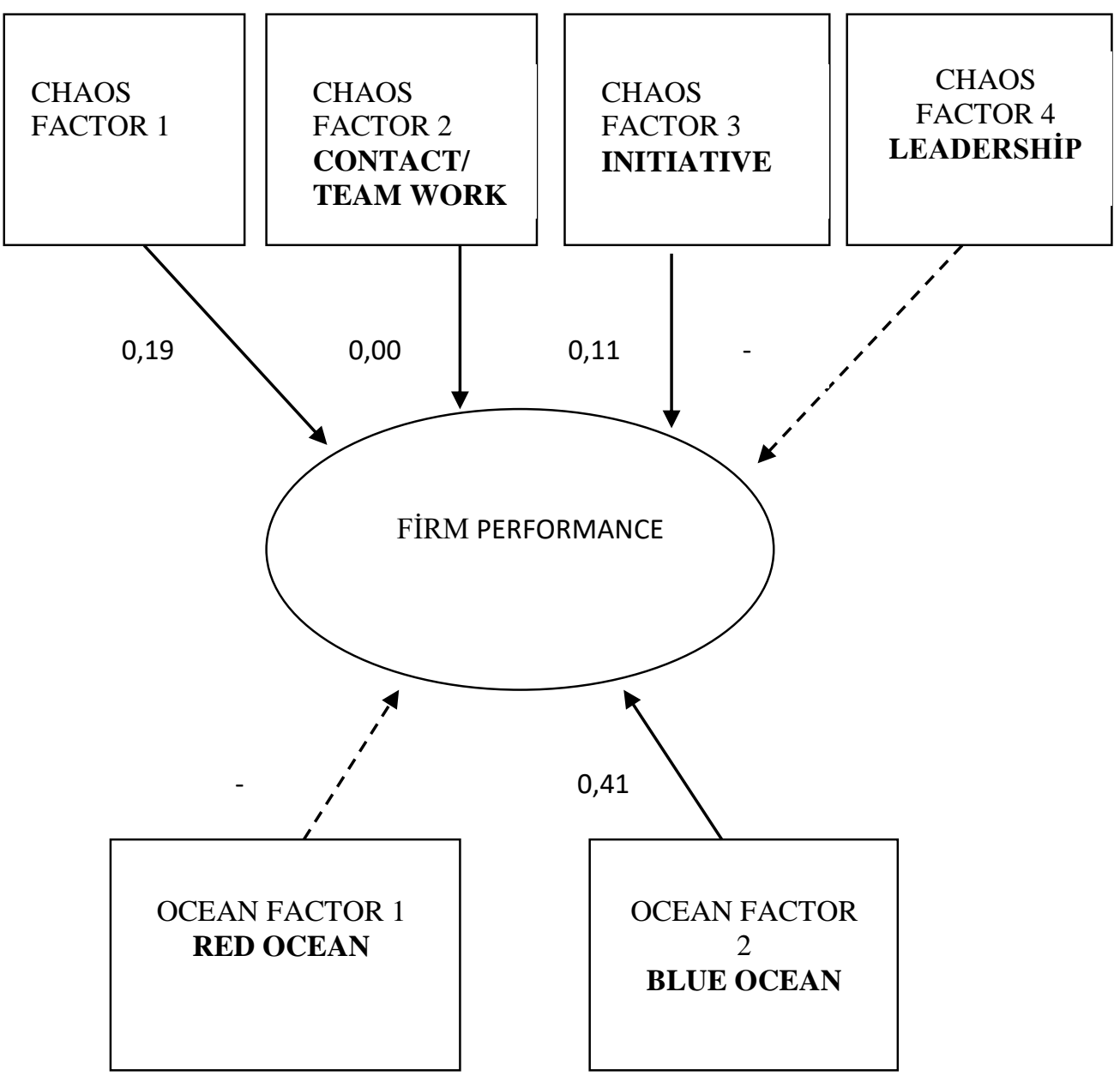

The model obtained in the study is presented in Figure 1. The correlations between the cases were determined by regression analysis. While dashed lines indicate a negative correlation, straight lines indicate a positive correlation.

\section{CONCLUSION}

Nowadays, firms should make competition meaningless to continue their existence in the existing market and to increase their performance in order to achieve success under ever-changing world conditions. The increased competition with globalization poses a threat for firms, and therefore, firms need innovative approaches and the ability to manage change. They have to constantly improve themselves and ensure their stability in the market in order to respond to the demands and needs of consumers early and in a timely manner. Therefore, they should be able to apply new management models other than the conventional management approach. They need modern management strategies to keep up with the changing age and to increase creativity outside the hierarchical order. In our study, since firms need good managers to increase their performance, managers need people who are open to innovation, support creativity and manage this situation in an irregularity.

Firms should be aware of the concept of chaos and have the ability to think about the butterfly effect and its consequences with the actions to be taken in order to maintain financial superiority, which is their goal of existence under changing conditions. In order for businesses to be open to innovation and catch up with age, they should know the concept of BOS and have an organizational culture that is open to innovation, and therefore, they should have managers who are aware of them. 
At the beginning of this study, it was started based on the following known issues:

- Chaos theory and blue ocean strategy are effective among modern strategic management techniques.

- Firms that adopt chaos theory have high performance.

- Firms that adopt the blue ocean strategy have high performance.

- Contributions of this study to the literature are as follows:

- Chaos theory positively affects the performance of firms.

- The blue ocean strategy positively affects the performance of firms.

- The red ocean strategy negatively affects the performance of firms.

- The validity of the theories was retested.

In this study, the historical development of the blue ocean strategy and chaos theory, how they can provide benefits, and successful examples in previously applied businesses were also included to better understand the BOS and Chaos Theory and to provide benefits for business managers. In this context, it can be said that this study may provide benefits for business owners, employees, and managers to achieve success in today's business world.

Recommendations to researchers: In this study, two independent variables were considered as Chaos Theory and BOS, and firm performance was used as the dependent variable. More objective data will be obtained if this study can be conducted with different firms and a higher number of participants.

Recommendations to managers: Managers should be able to apply modern strategic management techniques so that firms can increase their performance in the competitive business world. In this context, it will be beneficial for them to receive education and to do research on this issue. According to the results of the study, it was revealed that BOS and Chaos Theory had an effect on firm performance by $45 \%$, which is a very high rate. In the study, although there was an expected result in line with the blue ocean and chaos theory hypotheses, the red ocean strategy was not found to be significant, although it had a negative trend.

\section{REFERENCES}

Ağca, V., and Ender T. (2006). Multidimensional performance evaluation models and a balanced scorecard application. Afyon Kocatepe Üniversitesi iiBF Dergisi, 8 (1): 173-193.

Akal, Z. (2000). İşletmelerde Performans Ölçüm ve Denetimi: Performance Measurement and Control in Business. Ankara: Milli Prodüktivite Merkezi Yayınları.

Akdemir Ö, (2016). The changing profile of entrepreneurs in the knowledge age. Istanbul Üniversitesi Siyasal Bilgiler Fakültesi Dergisi,(55), 55-65.

Akmansoy, V., and Kartal S., (2014). Kaos teorisi ve eğitime yansımaları: Mehmet Akif Ersoy Üniversitesi örneği. Kuram ve Uygulamada Eğitim Yönetimi, (14), 499-518.

Altun, S. (2001). Kaos ve yönetim. Kuram ve Uygulamada Eğitim Yönetimi, Sayı Nu.28, 451-469.

Arıcıoğlu, M., and Karabıyık H. (2019). Örgütlerin geleceğine bir önerme olarak kaos teorisi ve kaos olgusunu anlamak. Medeniyet ve Toplum Dergisi, 3(29): 145-156.

Armour, P. (2016). Chaos is no catastrophe. Communications of the ACM, 59(4).

Baltaş, A. (2007). Rekabette Kalıcı Fark Yaratmak. http://www.acarbaltas.com/ makalelerphp? id= 82\#.VWD3vOb7LIU

Bartlett, S. (1950). Tests of significance in factor analysis. British Journal of Psychology, Statistical Section, (3): 77-85.

Barwise, P., and Séan M. (2012). Innovation beyond Blue Oceans. Market Leader, (4): 24-27.

Baykal, E., and Mırrak, F. (2019). Leading factors contributing international organizations to be agile and blue ocean strategy: an evidence from Turkish civil aviation sector. Stratejik ve Sosyal Araştırmalar Dergisi, 3 (3): 465-490.

Becker, H. (2013). IMAX Move to Hollywood: Blue Ocean Strategy or a case of who moved my Cheese. Global Conference on Business and Finance Proceedings, 8 (2): 472-476.

Borgianni, Y, Gaetano, C., and Federico, R., (2012). Investigating the patterns of value-oriented innovations in blue ocean strategy. International Journal of Innovation Science, 4 (3): 123-142.

Bright, E. H., and Robert G. L., (2005). The chaos theory of careers. The Career Development Quarterly, (53): 291-305. 
Burke, A., André S. and Roy T., (2010). Blue ocean vs. five forces. Harward Business Review, (88): 28.

Burns, S., (2009). Chaos theory and leadership studies: exploring uncharted seas. Journal of Leadership \& Organizational Studies, 9 (2): $42-56$.

Chang, S. (2010). Bandit cellphones: a blue ocean strategy. Technology in Society, (32): 219-223.

Cirjevskis, A., Genadijs H. and Valērija L. (2011). How to implement blue ocean strategy (BOS) in B2B sector. Business Management and Education, 9 (2): 201-215.

Çavuş, F., İnce, Z., Yakut, E., Akbulut, M., and Kalkan, A. (2016). Kaos ve durumsallık: bir değerlendirme. Kahramanmaraş Sütçü İmam Üniversitesi Sosyal Bilimler Dergisi, 13 (2): 207-210.

Çıraklı, Ü., Dalkılıç, S. and Hacıhasanoğlu, T. (2017). Kaos teorisi, karmaşıklık teorisi, karmaşık uyarlamalı sistemler: sağıı hizmetleri açısından bir derleme. 3(6), 330-343.

Demirtaş, H. (2000). Kriz yönetimi. Kuram ve Uygulamada Eğitim Yönetimi,23 (6): 353-373.

Dorf, M. (2014). Blue Ocean Leadership. Harward Business Review, 60-72.

Eden, A., (1994). Katastrof ve Kaos Teorileri Hakkında. http://www.Matematikdunyasi.org/arsiv/PDF_eskisayilar/1994_1_6_11_KATASTROF.pdf

Elitaş, C., and Veysel A. (2006). Firmalarda çok boyutlu performans değerleme yaklaşımları: kavramsal bir çerçeve. Afyon Kocatepe Üniversitesi Sosyal Bilimler Dergisi, 8 (2): 347-368.

Ergen, A. (2015). Stratejik düşünce yaratma: mavi okyanusa yelken açmak. Bahçeşehir Üniversitesi Dergisi, http://pazarlama.org.tr/dergi/yonetim/icerik/ makaleler/21-published.pdf.

Erol, M. (2009). Düzen, kaos ve değişme. Türkiyet Araştırmaları, 125-155.

Ertürk, A. (2012). Kaos kuramı. Kastamonu Ĕgitim Dergisi, 20 (3): 849-868.

Fatih, H. (2006). Kaos teorisi ve yönetimde yeni yaklaşımlar. Süleyman Demirel Üniversitesi, Vizyoner Dergisi, 9(22): 161-168.

Galacgac, J., and Singh, A., (2016). Implications of chaos theory. Chaotic Modelling and Simulation, (4): 515-527.

Giannoulis, C. and Jelena Z. (2012). Linking strategic innovation to requirements: a look into blue ocean strategy. Sandhkul ve Seigerroth (Ed.) 5th IFIP WG 8.1 Working Conference, POEM, 118-128.

Gökmen, A. (2009). Kaos teorisinin genel bir değerlendirmesi. Hitit Üniversitesi Sosyal Bilimler Enstitüsü Dergisi, 2 (1): $61-79$.

Gündüz, Ş. (2016). How to make blue ocean turning into red ocean blue again: a case study of a room escape game. ADVED

Gündüz, Ş. (2018). Preventing blue ocean turning into red ocean again. Journal of Human Sciences, 15(1): 1-7.

Gündüz, Ş. (2019). Yükseköğretimde mavi okyanuslar. Üniversite Araştırmaları Dergisi, 1(3): 116-120.

Güneş, S. (2011). Değer yaratma bağlamında güncel dört yenilik modeli. Sanat ve Tasarım Dergisi, 1 (7): $71-89$.

Hein, K. (2005). Yellow tail tells its tale. Brandweek, 30-46.

Kahyaoğlu, M. (2015). Kaos teorisi çerçevesinde bireysel yatırımcı davranışının analizi. İşletme Bilimi Dergisi, 3 (1): $38-51$.

Kalkan, A., and Alparslan M., (2009). Rekabet savaşından çıkış yolu: değer yeniliği, kâr ve insan önermeleri. Mehmet Akif Ersoy Üniversitesi Sosyal Bilimler Dergisi, (1): 1-12.

Kaplan, R. and David P. (1996). Linking the balanced scorecard to strategy. California Management Review, 39 (1): $53-79$.

Karamustafa, O., Varıcı İ. and Er, B. (2009). Kurumsal yönetim ve firma performansı: IMKB kurumsal yönetim endeksi kapsamındaki firmalar üzerinde bir uygulama. Kocaeli Üniversitesi SBE Dergisi, (17): 100-119.

Kazdal, Ö. (2013). Aile şirketlerinde çağdaş yönetim modellerinin uygulanması üzerine Istanbul ilinde ampirik bir araştırma. Yüksek Lisans Tezi. T. C. Beykent Üniversitesi, SBE, 76.

Kim, W., and Renée M., (2014). Mavi Okyanus Stratejisi. Istanbul: CSA Global Publising, (11): 3-12.

Kim, W., and Renée M., (2004). Blue Ocean Strategy. Harvard Businesss Review. 82-10.

Kim, W., and Renée M., (2005). Blue Ocean Strategy: From Theory to Practice. California Management Review, 45 (3): 106.

Kim, W., and Renée M., (2015). Blue Ocean Strategy'nin Yazarları W. Chan Kim ve Renee Mauborgne ile Söyleşi. moodle.technion.ac.il, $118-119$.

Kim, C., Kyung H. and Jaekyung K. (2008). A strategy for third-party logistics systems: a case analysis using the blue ocean strategy. Omega, the International Journal of Management Science, (36): 522-533. 
Kişi, N. (2017). Etkili rekabet için mavi okyanus liderliği. Uluslararası Akademik Yönetim Bilimleri Dergisi: (4), $202-210$.

Koçel, T. (2005). İşletme Yöneticiliği. 10. Basım, Istanbul: Arıkan Basım Yayım, 492.

Leavy, B. (1996). Design thinking - a new mental model of value innovation. Strategy \&Leadership, 38(3): 5-14.

Lindic, J., Mojca B., and Helena K. (2012). Higher growth through the blue ocean strategy: implications for economic policy. Research Policy, (41): 928-938.

Lorenz, E. (1995). The Essence of Chaos. United Kingdom: UCL Press.

Mazlum, Ö. (2011). Rengin Kültürel Çağrışımları. Dumlupınar Üniversitesi SBE Dergisi, (31): 125-138.

Meyer, V. and Vipin G. (1994). The Performance Paradox', in Straw. Research in Organizational Behavior, 16 (3):309-369.

Mohammed, Z. (2009). Analysis of the Use of the Blue Ocean Strategy, Case Study Analysis on 14 Different Analysis. Research Bulletin of the Faculty of Economics, 28-34.

Mutluay, A. and Tuncay, T. (2013). Döviz Kuru Değişimlerinin Firma Performansına Etkileri: Türkiye Örneği. BDDK Bankacılık ve Finansal Piyasalar, 7 (1): 59-78.

Öge, S. (2005). Düzen mi Düzensizlik (Kaos) mi? Örgütsel Varlığın Sürdürülebilirliği Açısından bir Değerlendirme. Selçuk Üniversitesi SBE Dergisi, (13):285-303.

Özen, H., and Süleyman, K. (2013). An Applicaton of Chaos Theory to Educational Administrator's Behavior: Overwhelming the Cheating Crisis on An Exam. International Journal of Academic Research, 5 (3): 130-135.

Öztürk, Z. and Kızılkaya, S. (2017). Chaos Complexity Theory at Management. International Online Journal of Education and Teaching, 4(3): 259264.

Özutku, H., and Çetinkaya, M. (2012). Stratejik İnsan Kaynakları Yönetimi ve Firma Performansı Arasındaki i̇lişkide İçsel ve Dışsal Uyumun Moderatör Etkisi: Türk Otomotiv Sektöründe Bir Alan Araştırması. Ege Akademik Bakış, 12 (3): 351-367.

Pryor, G. L., and Jim E. H. (2009). Game as a Career Metaphor: A Chaos Theory Career Counselling Application. British Journal of Guidance \& Counselling, 39-50.

Rau, J. G. (2012). With Your Idea, are You Trying to Navigate the Red Ocean or the Blue Ocean Inventors. Digest, InventorsDigest.com.

Speakman, M. and Richard S. (2012). A Chaos Theory Perspective on Destination Crisis Management: Evidence from Mexico. Journal of Destination Marketing \& Management, 1(1): 67-77.

Thiétart, R. and Bernard F. (1995). Chaos Theory and Organization. Organization Science, 6(1): 1-145.

Tu, J., Min-Chieh S., Chuan-Ying H., and Jian-Hao L. (2014). Developing Blue Ocean Strategy of Sustainable Product Design and Development for Business Opportunities of BOP Groups in Taiwan. Mathematical Problems in Engineering, Mathematical Problems in Engineering, 1-23.

Turunç, Ö. (2008). Uluslararası Güvenlık Düzlemine Yönetim Bilimi Penceresinden Farklı bir Bakış Stratejik Kaos Yönetimi Yaklaşımı. Güvenlik Stratejileri Dergisi, (8): 45-72.

Wengel, J., Ferreira-Villegas, G. B., Pérez-Hernández, G., \& Suárez-Cruz, L. M. (2010). Schumpeter and the blue ocean strategy. Revista de la Maestría en Derecho Económico, 6(6), 53-85.

Yakut, H., (2018). Kaos Teorisi ve Yönetimde Yeni Arayışlar. Süleyman Demirel Üniversitesi Vizyoner Dergisi, 9(22): 161-168.

Yiğit, S. (2015). Değer İnovasyonu: İnovasyonla Değer Oluşturmak. Ekonomik ve Sosyal Araştırmalar Dergisi, (11): $227-244$.

Yüksel, M and Esmer, Y. (2019). İşletme Yönetiminde Kaos Yaklaşımı: Teorik Bir Bakış. Opus Uluslararası Toplum Araştırmaları Dergisi, (18): 937952.

Yüreğir, O. and Nakıboğlu,, G. (2007). Performans Ölçümü ve Ölçüm Sistemleri: Genel Bir Bakış. Ç. Ü. Sosyal Bilimler Dergisi, 16(2): 545-562.

Zerenler, M. (2003). Kriz Dönemlerinde İşletmelerde Üretim Süreci Esnekliğinin Şirketlerin Performans ve Yaşam Sürelerine Etkileri. Doktora Tezi, Selçuk Üniversitesi, SBE.

Zerenler, M., and Rifat I., (2006). Kriz Dönemlerinde Ürün ve Süreç Esnekliğinin İşletme Performansına Etkileri: Küçük ve Orta Ölçekli Tekstil İşletmelerinde Bir Araştırma. Erciyes Üniversitesi Sosyal Bilimler Enstitüsü Dergisi, 1(21): 247-267. 